\title{
PENGARUH JENIS BAMBU DAN UKURAN PARTIKEL TERHADAP SIFAT FISIK PAPAN SEMEN
}

\section{EFFECT OF BAMBOO SPECIES AND SIZE PARTICLES TO THE PHYSICAL PROPERTIES OF CEMENT BOARD}

\author{
M. Loiwatu ${ }^{1)}$; Viktor Kewilaa ${ }^{2)}$; Olga Nataly da Costa ${ }^{3)}$ \\ Fakultas Pertanian, Jurusan Kehutanan Universitas Pattimura-Ambon \\ Email: meyche loiwatu@gmail.com
}

\begin{tabular}{|l|l}
\hline Diterima: 27 Agustus 2019 & Disetujui : 15 September 2019
\end{tabular}

\begin{abstract}
Abstrak
Tujuan dari penelitian ini adalah untuk mengukur efek spesies bambu dan jenis partikel terhadap sifat fisik papan semen. Jenis partikel kayu yang digunakan dalam papan semen adalah serbuk gergaji, serpihan, dan campuran serpihan dan serbuk gergaji. Percobaan faktorial dalam desain lengkap acak diterapkan dalam penelitian ini dengan dua faktor seperti spesies bambu (Dendrocalamus asper, Backe), (Gigantochloa atter (Hask) Kurz ex Munro) dan (Bambussa vertilatta), dan jenis partikel kayu (serbuk kayu, serpihan, dan campuran serpihan dan serbuk gergaji). Hasil penelitian menunjukkan bahwa jenis partikel kayu berpengaruh sangat signifikan terhadap papan semen seperti kepadatan papan dalam kondisi kering oven dan kondisi udara kering. Kombinasi spesies bambu dan jenis partikel kayu berpengaruh signifikan terhadap pembengkakan ketebalan papan. Spesies bambu tidak berpengaruh signifikan terhadap sifat fisik papan.
\end{abstract}

Kata kunci: bambu,ukuran partikel, papan semen

\begin{abstract}
Objective of the study was to measure effect of bamboo species and the types of particles to the physical properties of cement board. Type of wood particles used in cement board were sawdust, flake, and mixture of flake and sawdust. Factorial experiment in randomized complete design was applied in the study with two factors such as species of bamboo (Dendrocalamus asper, Backe), (Gigantochloa atter (Hask) Kurz ex Munro) and (Bambussa vertilatta), and type of wood particles (sawdust, flake, and mixture of flake and sawdust). Result of the study indicated that types of wood particles was highly significant effect to the cement board such as density of board in oven dry condition and air dry condition. Combination of species of bamboo and types of wood particles was significant effect to the thickness swelling of the board. Species of bamboo was not significant effect to physical properties of the board.
\end{abstract}

Keywords: bamboo, size particles, Cemen board. 


\section{PENDAHULUAN}

Bambu di Indonesia sudah ada sejak lama dikenal dan sudah menjadi bagian dari kehidupan. Menggunakan bambu untuk keperluan sehari-hari dan menjadikan bambu sebagai bahan baku serba guna, yaitu bahan bangunan, peralatan dapur, alat musik, obatobatan dan juga untuk makanan (rebung). Dewasa ini bambu telah di manfaatkan untuk pembuatan kertas, sumpit, bambulapis (plybamboo), mebel, maupun barang-barang kerajinan tangan sebagai cendramata.Hasil kerajinan tangan dari bambu telah menjadi salah satu komoditi ekspor hasil hutan.(Manuhua dkk, 2007).

Potensi Bambu di Maluku yang terbesar di Taniwel berada pada desa Buria dengan luas 650 hektar. Untuk kecamatan Kairatu bambu tumbuh pada beberapa tempat: Seriholo, Tala, Sumeit, Pasinaro, Ahiolo-Abia,Watui, Huku kecil, Rumakai, Latua, Hualoi. Menurut masyarakat setempat ada 9 jenis bambu yang dipergunakan secara tradisional.

Bambu-bambu tersebut dikenal dengan nama bambu Jawa (Gigantochloa atter), dimanfaatkan untuk pancuran rumah, bambu Sero (Gigantochloa apus), di manfaatkan untuk menangkap ikan, dan lebih banyak digunakan sebagai pagar halaman karena tahan terhadap serangan kumbang, pancuran air, wadah memasak makanan, rakit. Bambu suanggi (Schizostachyium brechycladum) dan bambu baduri (Bambusa blumeana) dimanfaatkan sebagai tongkat (steling) dalam membangun rumah dan bahan baku dalam membuat pemukul batang sagu yaitu nani. Bambu petung
(Dendrocalamus asper) di manfaatkan sebagai bahan konstruksi rumah (tiang), rebungnya sangat disukai penduduk dan bahan baku pabrik sumpit yang pernah beroperasi di Taniwel.

Bambu loleba (Bambusa atra) untuk bahan anyaman seperti nyiru, tali pengikat dalam menjahit daun sagu menjadi atap rumah, alat pemetik buah dan kaso atap. Bambu tui (Schizostachyum lima) dan bambu tapir digunakan untuk anyaman, alat musik (suling) dan rebungnya dapat di makan. Bambu tutul (Bambusa vulgaris) digunakan sebagai tanaman hias dan telah dicoba oleh pengrajin bambu untuk dijadikan meja kursi yang dipergunakan dalam pembuatan funiture di desa Morekao Kecamatan Piru.

Maloney (1977) menyebutkan bahwa bentuk dan ukuran partikel atau geometri partikel merupakan karakteristik yang esensial dari tipe dan ukuran partikel. Geometri partikel ini merupakan salah satu faktor dasar yang mempengaruhi papan semen partikel selain jenis bambu dan kondisi pengempaan.

Sifat fisik sangat berpengaruh terhadap pembuatan papan semen. Kadar air partikel yang tinggi akan mengakibatkan pengenceran bahan pengikat. Hal ini akan mengakibatkan kegagalan perekat karena garis perekat kurang saling mengikat. Faktor lain yang sangat penting dalam pembuatan papan semen partikel adalah kerapatan. Fakor kerapatan papan semen dapat menentukan baik tidaknya kualitas papan semen partikel. Salah satu tujuan produksi papan semen ialah untuk mempertahar kerapatan serendah mungkin dan menghas: 
sifat kekuatan yang disyaratkan (Haygreen dan Bowyer, 1966).

Industri papan semen adalah salah satu industri kayu yang sangat menunjang usaha pemerintah dalam penyediaan rumah untuk memenuhi kebutuhan karena papan semen dapat dipergunakan sebagai plafon, lantai dan dinding penyekat. Keunggulan papan semen dibanding dengan bahan bangunan lainnya adalah tahan api dan tahan rayap. Disamping itu industri papan semen merupakan salah satu industri yang dimanfaatkan secara optimal karena dapat digunakan berupa limbah, baik limbah eksploitasi maupun limbah industri (Kamil, 1970). Papan semen merupakan salah satu bahan bangunan yang tahan lama dalam pengunaannya sehingga biaya pemeliharaan rumah yang terbuat dari papan semen partikel lebih murah dan berkualitas.

Untuk itu penelitian ini diarahkan pada "Pengaruh Jenis Bambu dan Ukuran Partikel Terhadap Sifat Fisik Papan Semen", Penelitian ini bertujuan untuk mengetahui pengaruh jenis bambu dan ukuran partikel terhadap sifat fisik papan semen.

\section{METODOLOGI PENELITIAN}

\section{Tempat dan Waktu Penelitian}

Penelitian ini dilakukan pada dua lokasi yaitu pembuatan sampel uji dilakukan pada Laboratorium Teknologi Kayu, Jurusan Kehutanan, Fakultas Pertanian, Universitas Pattimura dan di SMK Negeri 4 Ambon. Penelitian ini dilaksanakan dari bulan Maret sampai dengan bulan Oktober 2012.

\section{Bahan dan Alat Penelitian}

\section{Bahan Penelitian}

Bahan baku yang dibutuhkan dalam penelitian ini yaitu bambu petung (Dendrocalamus asper), bambu jawa (Gigantochloa atter) dan bambu Suanggi (Bambussa vertillata), Adapun bahan tambahan yang dipakai sebagai perekat yaitu semen portland, air dan kapur $\left(\mathrm{CaCl}_{4}\right)$ sebagai katalisator.

\begin{abstract}
Alat - Alat Penelitian
Peralatan yang digunakan dalam penelitian ini antara lain :

Cetakan papan semen $30 \mathrm{~cm} \times 25 \mathrm{~cm}$ x $3 \mathrm{~cm}$, alat kempa, timbangan, desikator, gelas ukur, oven, ember, kantung plastik, aquades, kalkulator, kamera digital, termometer, spidol, penjepit, baskom, sarung tangan, trofol, gergaji besi, skap, parang, gergaji, caliper dan alat tulis menulis.
\end{abstract}

\section{Prosedur Kerja}

1) Bambu yang sudah dibersihkan dari kulitnya kemudian di belah, diskap untuk mendapatkan limbah serbuk dan limbah serutan bambu.

2) Serutan dan serbuk Bambu ditimbang 5gr, di masukkan ke dalam oven untuk proses pengeringan, setelah itu dimasukkan dalam desikator dan di timbang.

3) Setelah itu bahan tersebut direndam dan diambil dari rendaman dan dipindahkan dalam katalisator (berupa larutan air kapur) atau larutan $\mathrm{CaCl}_{2}$ sebanyak 2-3\% 
Pencelupan dalam larutan tersebut dilakukan sekitar 15-30 menit saja.

4) Bahan bambu tersebut selanjutnya diambil dan di campur semen sesuai dengan perbandingan semen : bahan baku : air (3:1:1).

5) Setelah pencampuran merata maka bahan bambu yang telah dicampurkan semen tersebut dibuat MAT (cetakan sementara). Pengepresan dalam cetakan MAT kira-kira 15-30 menit saja.

6) MAT selanjutnya diambil dan dimasukkan dalam pres dengan tekanan $1.000 \mathrm{~kg} / 30 \mathrm{~cm} \times 25 \mathrm{~cm} \times 3 \mathrm{~cm}$. Ukuran pres akhir harus sudah dibuat sedemikian rupa sehingga tebal papan

semen yang diinginkan sudah di stel (diberi sticker)

7) Setelah selesai pengepresan, papan semen diambil dan segera di anginanginkan (minimal 2 minggu) dan kemudian dipotong sesuai dengan ukuran.

\section{HASIL DAN PEMBAHASAN}

\section{Kadar Air Kondisi Kering Udara}

Nilai rata-rata kadar air papan semen pada kondisi kering udara disajikan tabel.1, Sedangkan hasil pengujian disajikan pada tabel 1.

Tabel. 1. Nilai rata-rata kadar air papan semen pada kondisi kering udara (\%)

\begin{tabular}{c|c|c|c|c}
\hline \multirow{2}{*}{ Jenis Bambu } & \multicolumn{3}{|c|}{ Jenis partikel } & \multirow{2}{*}{ Rata-rata } \\
\cline { 2 - 4 } & b1 & b2 & b3 & \\
\cline { 2 - 4 } & (serbuk) & (serutan) & (campuran) & \\
\hline a1 (Bambu Petung) & 5.1 & 3.0 & 5.2 & 4.43 \\
\hline a2 (Bambu Jawa) & 4.0 & 4.3 & 4.1 & 4.13 \\
\hline a3 (Bambu Suanggi) & 6.9 & 3.9 & 7.0 & 5.93 \\
\hline Rerata & 5.33 & 3.73 & 5.43 & 4.83 \\
\hline
\end{tabular}

Nilai rata-rata kadar air papan semen pada kondisi kering udara berdasarkan jenis bambu (faktor A), tertinggi pada jenis bambu suanggi (a3) sebesar $5.93 \%$, diikuti oleh jenis bambu petung (a1) $4.43 \%$ dan terendah pada jenis bambu jawa (a2) sebesar 4.13\%. sedangkan kadar air papan semen berdasarkan ukuran partikel (faktor B), tertinggi pada jenis partikel campuran serbuk dan serutan (b3) sebesar $5.43 \%$, diikuti oleh jenis partikel serbuk (b1)
5.33\% dan terendah pada jenis partikel serutan (b2) sebesar 3.73\%. hal ini disebabkan karena pada campuran serbuk dan serutan bambu kandungan airnya lebih tinggi pada lapisan permukaan menyebabkan pemampatan yang lebih tinggi saat pengempaan berlangsung (Haygreen dan Bowyer,1996) sehingga kadar air papan semen berdasarkan ukuran partikel tertinggi ada pada campuran serbuk dan serutan 
serta pada serbuk dan begitu pun sebaliknya

pada serutan.

Tabel 2. Analisis keragaman kadar air papan semen kondisi kering udara (\%)

\begin{tabular}{c|c|c|c|c|c|c}
\hline $\begin{array}{c}\text { Sumber } \\
\text { Keragaman }\end{array}$ & $\mathrm{db}$ & $\mathrm{JK}$ & $\mathrm{KT}$ & $\mathrm{F}$ & $\mathrm{F}_{0,05}$ & $\mathrm{~F}_{0,01}$ \\
\hline (Jenis Bambu) A & 2 & 16.56 & 8.28 & $2.10^{\text {tn }}$ & 3.55 & 6.01 \\
\hline (Ukuran Partikel) B & 2 & 17.12 & 8.56 & $2.17^{\text {tn }}$ & 3.55 & 6.01 \\
\hline AxB & 4 & 11.89 & 2.97 & $0.75^{\text {tn }}$ & 2.93 & 4.58 \\
\hline Galat & 18 & 71.11 & 3.95 & & & \\
\hline Total & 26 & 116.68 & & & & \\
\hline
\end{tabular}

keterangan $:$ th $=$ tidak nyata

Hasil analisis keragaman pada tabel 2. kadang bervariasi antara 5-12\%. Hal ini Menunjukkan bahwa faktor jenis bambu (A), jenis partikel (B) dan interaksi (AB), ketiganya tidak nyata terhadap kadar air papan semen kondisi kering udara. Data penelitian menunjukkan bahwa kadar air papan semen berkisar antara $2.55-10.13 \%$ kadar air dalam pengeringan menurut (Pelu, 2010) berkisar tergantung pada tipe dan jumlah perekat dan tingkat pembasahan lapisan sebelum dikempa.

\section{Kadar Air Kondisi Kering Oven}

Nilai rata-rata kadar air papan semen pada kondisi kering oven disajikan tabel.3. Sedangkan hasil pengujian disajikan pada tabel 3. antara 3-6\% dari berat kering oven kadang-

Tabel 3. Nilai rata-rata kadar air papan semen pada kondisi kering oven (\%)

\begin{tabular}{c|c|c|c|c}
\hline \multirow{2}{*}{ Jenis Bambu } & \multicolumn{3}{|c|}{ Jenis partikel } & \multirow{2}{*}{ Rata-rata } \\
\cline { 2 - 4 } & $\mathrm{b} 1$ & $\mathrm{~b} 2$ & $\mathrm{~b} 3$ & \\
\cline { 2 - 4 } & (serbuk) & (serutan) & (campuran) & \\
\hline a1 (Bambu Petung) & 8.6 & 7.1 & 8.6 & 8.1 \\
\hline a2 (Bambu Jawa) & 9.6 & 8.9 & 8.4 & 8.96 \\
\hline a3 (Bambu Suanggi) & 11.1 & 8.2 & 8.2 & 9.16 \\
\hline Rerata & 9.76 & 8.06 & 8.4 & 8.74 \\
\hline
\end{tabular}

Nilai rata-rata kadar air papan semen pada kondisi kering oven berdasarkan jenis bambu (faktor A), tertinggi pada jenis bambu suanggi (a3) sebesar $9.16 \%$, diikuti oleh jenis bambu jawa (a2) $8.96 \%$ dan terendah pada jenis bambu petung (a1) sebesar $8.1 \%$. sedangkan kadar air papan semen kondisi kering oven berdasarkan ukuran partikel (faktor B), tertinggi pada jenis partikel campuran serbuk (b1) sebesar 9.76\%, diikuti oleh jenis partikel serutan (b2) 8.06\% dan terendah pada jenis partikel campuran serbuk dan serutan (b3) sebesar 8.4\%. hal ini disebabkan karena udara, gas, dan uap air akan menguap akibat transfer panas secara konveksi dan panas diubah menjadi panas konduksi pada permukaan bahan dan dinding oven. Rendahnya kelembaban udara dalam oven menciptakan tekanan uap yang menyebabkan perpindahan air dari bagian dalam bahan menuju permukaan bahan, perluasan hilangnya air bahan ditentukan 
oleh sifat alami bahan dan laju pemanasan dan

dalam oven (Fellow, 2001).

perpindahan air pada saat pengeringan bahan

Tabel 4. Analisis keragaman kadar air papan semen kondisi kering oven (\%)

\begin{tabular}{c|c|c|c|c|c|c}
\hline $\begin{array}{c}\text { Sumber } \\
\text { Keragaman }\end{array}$ & $\mathrm{db}$ & $\mathrm{JK}$ & $\mathrm{KT}$ & $\mathrm{F}$ & $\mathrm{F}_{0,05}$ & $\mathrm{~F}_{0,01}$ \\
\hline (Jenis Bambu) A & 2 & 5.96 & 2.98 & $1.19^{\text {tn }}$ & 3.55 & 6.01 \\
\hline (Ukuran Partikel) B & 2 & 15.16 & 7.58 & $3.02^{*}$ & 3.55 & 6.01 \\
\hline AxB & 4 & 9.20 & 2.30 & $0.92^{\text {tn }}$ & 2.93 & 4.58 \\
\hline Galat & 18 & 45.24 & 2.51 & & & \\
\hline Total & 26 & 75.57 & & & & \\
\hline
\end{tabular}

keterangan : $*=$ berbeda nyata, $\mathrm{tn}=$ tidak nyata

Hasil analisis keragaman pada tabel 4. pengeringan dapat dipilih sesuai dengan yang Menunjukkan bahwa jenis Partikel (B), berbeda nyata terhadap papan semen kondisi kering oven, sedangkan jenis bambu (A) dan interaksi (AB) keduanya tidak nyata terhadap kadar air papan semen kondisi kering oven. Hal ini disebakan karena proses pengeringan yang terjadi pada oven yaitu panas yang diberikan pada bahan panas, dan melalui konduksi melalui wadah tempat bahan diletakkan. Pengeringan diperlukan, tidak memerlukan tempat yang luas dan kondisi pengeringan dapat dikontrol (Widodo dan Hendriadi, 2004).

\section{Kerapatan Papan Semen Kondisi Kering Udara $\left(\mathrm{Kg} / \mathrm{Cm}^{3}\right)$}

Nilai rata-rata Kerapatan papan semen pada kondisi kering udara disajikan tabel 5 . Sedangkan hasil pengujian disajikan pada tabel. 6. oven tidak tergantung cuaca, kapasitas

Tabel 5. Nilai rata-rata Kerapatan papan semen pada kondisi kering udara $\left(\mathrm{kg} / \mathrm{cm}^{3}\right)$

\begin{tabular}{c|c|c|c|c}
\hline \multirow{2}{*}{ Jenis Bambu } & \multicolumn{3}{|c|}{ Jenis Partikel } & \multirow{2}{*}{ Rata-rata } \\
\cline { 2 - 4 } & $\mathrm{b} 1$ & $\mathrm{~b} 2$ & $\mathrm{~b} 3$ & \\
\cline { 2 - 4 } & (serbuk) & (serutan) & (campuran) & \\
\hline a1 (Bambu Petung) & 0.7 & 0.5 & 0.5 & 0.56 \\
\hline a2 (Bambu Jawa) & 0.7 & 0.4 & 0.5 & 0.53 \\
\hline a3 (Bambu Suanggi) & 0.6 & 0.5 & 0.5 & 0.53 \\
\hline Rerata & 0.66 & 0.46 & 0.5 & 0.54 \\
\hline
\end{tabular}

Nilai rata-rata Kerapatan papan semen pada kondisi kering udara berdasarkan jenis bambu (faktor A), tertinggi pada jenis bambu petung (a1) sebesar $0.5 \mathrm{~kg} / \mathrm{cm}^{3}$, diikuti oleh jenis bambu jawa (a2) $0.53 \mathrm{~kg} / \mathrm{cm}^{3}$ dan terendah pada jenis bambu petung (a3) sebesar $0.53 \mathrm{~kg} / \mathrm{cm}^{3}$, sedangkan kerapatan papan semen kondisi kering udara berdasarkan ukuran partikel (faktor B), tertinggi pada jenis partikel serbuk (b1) sebesar $0.66 \mathrm{~kg} / \mathrm{cm}^{3}$, diikuti oleh jenis partikel 
serutan (b2) $0.46 \mathrm{~kg} / \mathrm{cm}^{3}$ dan terendah pada jenis partikel campuran serbuk dan serutan (b3) sebesar $0.5 \mathrm{~kg} / \mathrm{cm}^{3}$. Hal ini disebabkan karena papan semen jenis bambu petung dan bambu suanggi yang berkerapatan tinggi mempunyai jumlah perekatan yang lebih banyak untuk mempunyai ketebalan tertentu sehingga akan lebih banyak partikel yang tertekan dan kontak antara partikel lebih baik. Jika dibandingkan dengan papan semen jenis bambu jawa yang berkerapatan rendah.

Tabel. 6. Analisis keragaman kerapatan papan semen kondisi kering udara $\left(\mathrm{kg} / \mathrm{cm}^{3}\right)$

\begin{tabular}{c|c|c|c|c|c|c}
\hline Sumber Keragaman & $\mathrm{db}$ & $\mathrm{JK}$ & $\mathrm{KT}$ & $\mathrm{F}$ & $\mathrm{F}_{0,05}$ & $\mathrm{~F}_{0,01}$ \\
\hline (Jenis Bambu) A & 2 & 0.000096 & 0.000048 & $0.01^{\text {tn }}$ & 3.55 & 6.01 \\
\hline (Ukuran Partikel) B & 2 & 0.287496 & 0.143748 & $28.41^{* *}$ & 3.55 & 6.01 \\
\hline AxB & 4 & 0.031704 & 0.007926 & $1.57^{\text {tn }}$ & 2.93 & 4.58 \\
\hline Galat & 18 & 0.091067 & 0.005059 & & & \\
\hline Total & 26 & 0.410363 & & & & \\
\hline Keterangan $: *^{*}$ berbeda sangat nyata, tn tidak nyata
\end{tabular}

Hasil analisis keragaman pada tabel 6. kekuatan papan yang makin tinggi pula kecuali Menunjukkan bahwa jenis Partikel (B), berbeda sangat nyata terhadap kerapatan papan semen kondisi kering udara, sedangkan jenis bambu (A) dan interaksi $(\mathrm{AB})$ keduanya tidak nyata terhadap kerapatan papan semen kondisi kering udara. Hal ini disebakan karena factor kerapatan kestabilan dimensi papan semen perendaman dalam air dan terhadap kelembaban yang tinggi (Maloney, 1997).

Untuk mengetahui sejauh mana pengaruh ukuran partikel (B) maka dilakukan uji beda nyata jujur yang dapat dilihat pada tabel 7 . papan semen yang lebih tinggi akan memberikan

Tabel 7. Uji Beda Nyata Jujur Kerapatan Papan Semen Kondisi Kering Udara $\left(\mathrm{Kg} / \mathrm{cm}^{3}\right)$

\begin{tabular}{|c|c|c|}
\hline Perlakuan & Rerata & Beda \\
\hline B1 & 0.70 & \\
\hline B2 & 0.48 & $0.22^{* *}$ \\
\hline B3 & 0.48 & $0.22 * *$ \\
\hline
\end{tabular}

Ket : BNJ 05 = 0,21 $\mathrm{BNJ01}=0,29$

Dari hasil uji beda nyata jujur pada tabel 7 , terlihat bahwa b1 berbeda sangat nyata terhadap b2 dan b3. Hal ini menunjukkan bahwa kerapatan yang dihasilkan dari serbuk berbeda dari kerapatan yang dihasilkan dari serutan dan campurannya.

Kerapatan Papan Semen Kondisi Kering Oven $\left(\mathrm{Kg} / \mathrm{Cm}^{3}\right)$
Nilai rata-rata Kerapatan papan semen pada kondisi kering oven disajikan tabel 8 sedangkan hasil pengujian disajikan pada tabel 9. 
Tabel. 8. Nilai rata-rata Kerapatan papan semen pada kondisi kering oven $\left(\mathrm{kg} / \mathrm{cm}^{3}\right)$

\begin{tabular}{c|c|c|c|c}
\hline \multirow{2}{*}{ Jenis Bambu } & \multicolumn{3}{|c|}{ Jenis partikel } & \multirow{2}{*}{ Rata-rata } \\
\cline { 2 - 4 } & $\mathrm{b} 1$ & $\mathrm{~b} 2$ & $\mathrm{~b} 3$ & \\
\cline { 2 - 4 } & (serbuk) & (serutan) & (campuran) & \\
\hline a1 (Bambu Petung) & 0.7 & 0.5 & 0.4 & 0.53 \\
\hline a2 (Bambu Jawa) & 0.7 & 0.4 & 0.5 & 0.53 \\
\hline a3 (Bambu Suanggi) & 0.7 & 0.5 & 0.5 & 0.56 \\
\hline Rerata & 0.7 & 0.46 & 0.46 & 0.54 \\
\hline
\end{tabular}

Nilai rata-rata Kerapatan papan semen pada kondisi kering oven berdasarkan jenis bambu (faktor A), tertinggi pada jenis bambu suanggi (a3) sebesar $0.56 \mathrm{~kg} / \mathrm{cm}^{3}$, diikuti oleh jenis bambu jawa (a2) $0.53 \mathrm{~kg} / \mathrm{cm}^{3}$ dan terendah pada jenis bambu petung (a1) sebesar $0.53 \mathrm{~kg} / \mathrm{cm}^{3}$. sedangkan Kerapatan papan semen kondisi kering udara berdasarkan ukuran partikel (faktor B), tertinggi pada jenis partikel serbuk (b1) sebesar $0.7 \mathrm{~kg} / \mathrm{cm}^{3}$, diikuti oleh jenis partikel campuran serbuk dan serutan (b3) $0.46 \mathrm{~kg} / \mathrm{cm}^{3}$ dan terendah pada jenis partikel serutan (b2) sebesar $0.46 \mathrm{~kg} / \mathrm{cm}^{3}$. Rendahnya kelembaban udara dalam oven menciptakan tekanan uap yang menyebabkan perpindahan air dari bagian dalam bahan menuju permukaan bahan, perluasan hilangnya air bahan ditentukan oleh sifat alami bahan dan laju pemanasan dan perpindahan air pada saat pengeringan bahan dalam oven.

Tabel. 9. Analisis keragaman kerapatan papan semen kondisi kering udara $\left(\mathrm{kg} / \mathrm{cm}^{3}\right)$

\begin{tabular}{c|c|c|c|c|c|c}
\hline $\begin{array}{c}\text { Sumber } \\
\text { Keragaman }\end{array}$ & $\mathrm{db}$ & $\mathrm{JK}$ & $\mathrm{KT}$ & $\mathrm{F}$ & $\mathrm{F}_{0,05}$ & $\mathrm{~F}_{0,01}$ \\
\hline (Jenis Bambu) A & 2 & 0.005119 & 0.002559 & $0.42^{\text {tn }}$ & 3.55 & 6.01 \\
\hline (Ukuran Partikel) B & 2 & 0.314696 & 0.157348 & $26.13^{* *}$ & 3.55 & 6.01 \\
\hline AxB & 4 & 0.031659 & 0.007915 & $1.31^{\text {tn }}$ & 2.93 & 4.58 \\
\hline Galat & 18 & 0.108400 & 0.006022 & & & \\
\hline Total & 26 & 0.410363 & & & & \\
\hline Keterangan :** berbeda sangat nyata; tn = tidak nyata
\end{tabular}

Hasil analisis keragaman pada tabel 9 . Menunjukkan bahwa jenis Partikel (B), berbeda sangat nyata terhadap kerapatan papan semen kondisi kering oven, sedangkan jenis bambu (A) dan interaksi (AB) keduanya tidak nyata terhadap kerapatan papan semen kondisi kering oven. Hal ini disebakan karena faktor papan semen yang dihasilkan dari partikel yang berbeda menghasilkan kerapatan papan semen pada kondisi kering oven yang berbeda pula. Untuk mengetahui sejauh mana pengaruh jenis partikel (b1,b2,b3) maka dilakukan uji beda nyata jujur yang dapat dilihat pada tabel 10 . 
Tabel.10. Uji Beda Nyata Jujur Kerapatan Papan Semen Kondisi Kering Oven $\left(\mathrm{Kg} / \mathrm{cm}^{3}\right)$

\begin{tabular}{c|c|cc}
\hline Perlakuan & Rerata & \multicolumn{2}{|c}{ Beda } \\
\hline B1 & 0.70 & & \\
\hline B2 & 0.47 & $0.22^{* *}$ & \\
\hline B3 & 0.46 & 0.22 & $0.01^{\text {tn }}$ \\
\hline
\end{tabular}

Ket : $\mathrm{BNJ} 05=0,134 \quad \mathrm{BNJ} 01=0,814$

Dari hasil uji beda nyata jujur pada tabel 12, terlihat bahwa kerapatan papan dari serbuk (b1) berbeda sangat nyata (b2) terhadap (b3)

\section{Penyerapan Air}

Tabel.11. Nilai rata-rata Kerapatan papan semen pada kondisi kering oven $\left(\mathrm{kg} / \mathrm{cm}^{3}\right)$

\begin{tabular}{c|c|c|c|c}
\hline \multirow{2}{*}{ Jenis Bambu } & \multicolumn{3}{|c|}{ Jenis partikel } & \multirow{2}{*}{ Rata-rata } \\
\cline { 2 - 4 } & $\mathrm{b} 1$ & $\mathrm{~b} 2$ & $\mathrm{~b} 3$ & \\
\cline { 2 - 4 } & (serbuk) & (serutan) & (campuran) & \\
\hline a1 (Bambu Petung) & 22.6 & 22.1 & 24.1 & 22.93 \\
\hline a2 (Bambu Jawa) & 22.8 & 21.4 & 22.7 & 22.30 \\
\hline a3 (Bambu Suanggi) & 16.0 & 19.7 & 19.7 & 18.46 \\
\hline Rerata & 20.46 & 21.06 & 22.16 & 21.23 \\
\hline
\end{tabular}

Nilai rata-rata penyerapan air papan semen berdasarkan jenis bambu (faktor A), tertinggi pada jenis bambu petung (a1) sebesar $22.93 \%$, diikuti oleh jenis bambu jawa (a2) $22.3 \%$ dan terendah pada jenis bambu suanggi (a3) sebesar $18.46 \%$. sedangkan penyerapan air papan semen berdasarkan ukuran partikel (faktor B), tertinggi pada jenis partikel campuran serbuk
Nilai rata-rata penyerapan air disajikan tabel 11 sedangkan hasil pengujian disajikan pada tabel 12 . 


\begin{tabular}{c|l|l|l|l|l|l}
\hline Galat & 18 & 373.17 & 20.73 & & & \\
\hline Total & 26 & 515.46 & & & & \\
\hline Keterangan : ** = sangat nyata & $\mathrm{tn}=$ tidak nyata
\end{tabular}

Hasil analisis keragaman pada tabel 12 diantara jalinan partikel yang makin kuat menunjukkan bahwa jenis bambu (A), jenis partikel (B) dan interaksi (AB) ketiganya menunjukkan pengaruh yang tidak nyata terhadap penyerapan air papan semen. Hal ini disebabkan karena ikatan antara partikel yang tidak kuat menyebabkan rongga atau pori menyebabkan rongga atau pori diantara jalinan partikel tidak banyak diisi oleh air.

\section{Pengembangan Tebal}

Nilai rata-rata Pengembangan Tebal disajikan table. 13 sedangkan hasil pengujian disajikan pada tabel. 14 .

Tabel.13. Nilai rata-rata penyerapan air papan semen (\%)

\begin{tabular}{c|c|c|c|c}
\hline \multirow{2}{*}{ Jenis Bambu } & \multicolumn{3}{|c|}{ Jenis partikel } & \multirow{2}{*}{ Rata-rata } \\
\cline { 2 - 4 } & $\mathrm{b} 1$ & $\mathrm{~b} 2$ & $\mathrm{~b} 3$ & \\
\cline { 2 - 4 } & (serbuk) & (serutan) & (campuran) & \\
\hline a1 (Bambu Petung) & 31.5 & 23.3 & 18.1 & 24.3 \\
\hline a2 (Bambu Jawa) & 29.7 & 36.4 & 19.6 & 28.6 \\
\hline a3 (Bambu Suanggi) & 21.9 & 29.2 & 28.6 & 26,56 \\
\hline Rerata & 27.68 & 29.63 & 22.10 & 26.5 \\
\hline
\end{tabular}

Nilai rata-rata pengembangan tebal papan semen berdasarkan jenis bambu (faktor A), tertinggi pada jenis bambu jawa (a2) sebesar $28.56 \%$, diikuti oleh jenis bambu suanggi (a3) $26.56 \%$ dan terendah pada jenis bambu petung (a1) sebesar $24.3 \%$. Sedangkan pengembangan tebal papan semen berdasarkan ukuran partikel (faktor B), tertinggi pada jenis partikel serutan (b2) sebesar $29.63 \%$, diikuti oleh jenis partikel serbuk (b1) $27.7 \%$ dan terendah pada jenis partikel campuran serbuk dan serutan (b3) sebesar $22.1 \%$. Hal ini disebabkan karena faktor perubahan dimensi serat akibat pengembangan dinding sel atau perubahan ukuran rongga serat akibat menyerap air, sehingga pengembangan tebal bamboo jawa dan bambu suanggi lebih tinggi hal ini juga di karenakan semakin tinggi kerapatan berarti tinggi pula pemampatan dimensinya, sehingga sifat pengembangan tebalnya semakin tinggi (Subiyanto, 2003) jika dibandingkan dengan bambu petung dan pengembangan tebalnya lebih rendah disebabkan karena daya serapnya kuran

Tabel.14. Analisis Keragaman Pengembangan Tebal Papan Semen

\begin{tabular}{c|c|c|c|c|c|c}
\hline $\begin{array}{c}\text { Sumber } \\
\text { Keragaman }\end{array}$ & $\mathrm{db}$ & $\mathrm{JK}$ & $\mathrm{KT}$ & $\mathrm{F}$ & $\mathrm{F}_{0,05}$ & $\mathrm{~F}_{0,01}$ \\
\hline (Jenis Bambu) A & 2 & 105.06 & 52.53 & $2.53^{\text {th }}$ & 3.55 & 6.01 \\
\hline
\end{tabular}




\begin{tabular}{c|c|c|c|c|c|c}
\hline (Ukuran Partikel) B & 2 & 13.19 & 6.59 & $0.32^{\text {tn }}$ & 3.55 & 6.01 \\
\hline AxB & 4 & 24.04 & 6.01 & $0.29^{\text {th }}$ & 2.93 & 4.58 \\
\hline Galat & 18 & 373.17 & 20.73 & & & \\
\hline Total & 26 & 515.46 & & & & \\
\hline
\end{tabular}

Keterangan : $\mathrm{tn}=$ tidak nyata

Hasil analisis keragaman pada tabel 14, menunjukkan bahwa jenis bambu (A), jenis partikel (B) dan interaksi (AB) ketiganya menunjukkan pengaruh tidak nyata terhadap penyerapan air papan semen. Hal ini

\section{KESIMPULAN DAN SARAN}

\section{Kesimpulan}

Berdasarkan hasil dan pembahasan dapat disimpulkan :

1. Kadar air kondisi kering udara papan semen yang terbuat dari jenis bambu suanggi tertinggi $(5.93 \%)$ dan terendah pada jenis bambu jawa (4.13\%); sedangkan ukuran partikel terhadap kadar air kering udara papan semen tertinggi pada ukuran campuran (5.43\%) dan terendah pada ukuran serutan $(3.73 \%)$;

2. Kadar air kondisi kering oven papan semen yang terbuat dari jenis bambu suanggi tertinggi (9.16\%) dan terendah pada jenis bambu petung (8.10\%); sedangkan Ukuran partikel kadar air kondisi kering oven tertinggi pada ukuran serbuk $(9.76 \%)$ dan terendah pada jenis campuran serbuk dan serutan $(8.40 \%)$.

3. Kerapatan kondisi kering udara papan semen yang terbuat dari jenis bambu petung tertinggi $\left(0.56 \mathrm{gr} / \mathrm{cm}^{3}\right)$ dan terendah pada jenis bambu suanggi disebabkan karena ikatan antara partikel yang tidak kuat menyebabkan rongga atau pori di antara jalinan partikel yang makin kuat menyebabkan rongga atau pori di antara jalinan partikel tidak banyak diisi oleh air. $\left(0.53 \mathrm{gr} / \mathrm{cm}^{3}\right)$; sedangkan Ukuran partikel kerapatan kondisi kering udara tertinggi pada ukuran serbuk $\left(0.66 \mathrm{gr} / \mathrm{cm}^{3}\right)$ dan terendah pada jenis serutan $\left(0.46 \mathrm{gr} / \mathrm{cm}^{3}\right)$.

4. Kerapatan kondisi kering oven papan semen yang terbuat dari jenis bambu suanggi tertinggi $\left(0.56 \mathrm{gr} / \mathrm{cm}^{3}\right)$ dan terendah pada jenis bambu petung $\left(0.53 \mathrm{gr} / \mathrm{cm}^{3}\right)$; sedangkan Ukuran partikel kerapatan kondisi kering oven tertinggi pada ukuran serbuk (0.70 $\mathrm{gr} / \mathrm{cm}^{3}$ ) dan terendah pada jenis serutan $\left(0.46 \mathrm{gr} / \mathrm{cm}^{3}\right)$.

5. Penyerapan air papan semen yang terbuat dari jenis bambu petung tertinggi $(22.93 \%)$ dan terendah pada jenis bambu suanggi (18.46\%); sedangkan Ukuran partikel penyerapan air tertinggi pada ukuran jenis campuran serbuk dan serutan (22.16\%) dan terendah pada jenis serutan $(20.46 \%)$.

6. Pengembangan tebal papan semen yang terbuat dari jenis bambu jawa tertinggi $(28.56 \%)$ dan terendah pada jenis bambu petung (24.30\%); 
sedangkan Faktor Ukuran partikel pengembangan tebal tertinggi pada ukuran jenis serutan (29.63\%) dan terendah pada jenis campuran serbuk dan serutan $(22.10 \%)$.

7. Jenis bambu faktor (A) tidak memberikan pengaruh terhadap parameter yang diteliti.

8. Faktor Ukuran partikel memberikan pengaruh yang sangat nyata terhadap kerapatan kondisi kering udara dan kerapatan kondisi kering oven sedangkan parameter lainnya tidak berpengaruh.

9. Interaksi $\mathrm{AB}$ (kombinasi/faktor) memberikan pengaruh yang nyata terhadap pengembangan tebal sedangkan parameter lainnya tidak berpengaruh.

\section{Saran}

Perlu penelitian lanjutan tentang sifat kimia dan mekanik papan semen dalam kaintannya dengan kekuatan dan keawetan.

\section{DAFTAR PUSTAKA}

Anonim, 2001. Pengembangan tebal dan penyerapan air.http://www. Pengembangan /tebal/ penyerapan air.htm. (diakses 08/02/13)

2003. Pengembangan tebal dan penyerapan air.http://www. Pengembangan /tebal/ penyerapanair.htm. (diakses 08/02/13)

, 2004. Pengembangan tebal dan penyerapan air. http://www. Pengembangan /tebal/ penyerapanair.htm. (diakses 08/02/13)
Berlian, A V dan Rahayu E, 1995. Jenis dan Prospek Bisnis Bambu, Penebar Swadaya, Jakarta.

Dransfiel dan Widjaja, 1995. Anatomi Bambu.

Dumanauw, J F. 1990. Mengenal Kayu. PT Gramedia. Jakarta.

Ginoga, 1977. Sifat Fisis dan Mekanis Bambu Hitam dan Bambu Apus.

Gaspersz, Z. 1989. Metode Perancangan Untuk Ilmi-ilmu Pertanian dan Ilmuilmu Teknik dan Biologi. Penerbit ARMICO.

Hadjib, N dan Karnasudirdja, 1986. Sifat Fisis dan Mekanis Bambu Andong, Bambu Bitung, Bambu Atter, Laporan Intern Pusat Penelitian dan Pengembangan Hasil Hutan dan Sosial Ekonomi Kehutanan, Bogor.

Haygreen, J G dan J. L. Bowyer, 1989. Hasil Hutan dan Ilmu Kayu. Terjemahan Soetjipto, A. H. Gajah Mada Press. Yogyakarta.

http://www.dephut.go.id/INFORMASI/litbang /teliti/bambu.htm.(diakses, 22/08/11)http://www.scribd.com/doc/51 528025/naskah-seminar-karakteristikbambu-petungdiakses, 22/08/11).

http://www.tnalaspurwo.org/media/pdf/kea_ba mbu_jawa_gigantochloa_atter.pdf (diakses, 22/08/11).

Kamil, R N. 1970. Prospek Papan Semen di Indonesia. Pengumuman No. 95. Lembaga Penelitian Hasil Hutan, Bogor

Kewilaa, B. 2009. Panel - panel Kay. Jurusan Kehutanan, Fakultas Pertanian Universitas Pattimura.

Maloney, 1977. Sifat-sifat Penting atau Keunggulan Papan semen.

Manuhua, E. 2001. Bahan Ajar Sifat Fisik Kayu. Jurusan Kehutanan Fakultas Pertanian Universitas Pattimura. 
